\title{
Modelling Energy Consumption, Carbon Dioxide Emissions and Economic Growth Nexus in Ethiopia: Evidence from Cointegration and Causality Analysis
}

\author{
Shemelis Kebede Hundie* \\ Department of Economics, Jigjiga University, Ethiopia
}

A R T ICLE INFO

\section{Research Article}

Received 15 December 2017

Accepted 01 March 2018

Keywords:

Economic growth

Energy consumption

Environmental Kuznets Curve

$\mathrm{CO}_{2}$ emissions

Ethiopia

*Corresponding Author:

E-mail: shimelis2012ju@gmail.com

\begin{abstract}
A B S T R A C T
Policy makers need to know the relationship among energy use, economic growth and environmental quality in order to formulate rigorous policy for economic growth and environmental sustainability. This study analyzes the nexus among energy consumption, affluence, financial development, trade openness, urbanization, population and $\mathrm{CO}_{2}$ emissions in Ethiopia using data from 1970-2014. The ARDL cointegration results show that cointegration exists among the variables. Energy consumption, population, trade openness and economic growth have positive impact on $\mathrm{CO}_{2}$ in the long-run while economic growth squared reduces $\mathrm{CO}_{2}$ emissions which confirms that the EKC hypothesis holds in Ethiopia. In the short-run urbanization and energy consumption intensify environmental degradation. Toda-Yamamoto granger causality results indicate the bi-directional causality between energy consumption and $\mathrm{CO}_{2}$ emissions, $\mathrm{CO}_{2}$ emissions and urbanization. Financial development, population and urbanization cause economic growth while economic growth causes $\mathrm{CO}_{2}$ emissions. Causality runs from energy consumption to financial development, urbanization and population which in turn cause economic growth. From the result, $\mathrm{CO}_{2}$ emissions extenuation policy in Ethiopia should focus on environmentally friendly growth, enhancing consumption of cleaner energy, incorporating the impact of population, urbanization, trade and financial development.
\end{abstract}

DOI: https://doi.org/10.24925/turjaf.v6i6.699-709.1720

\section{Introduction}

Energy which is used as widely as capital and labour is regarded as the basic input for the production process. Continuous energy supply is compulsory for sustaining and improving the current production level and standard of living since energy consumption is so extensive among the industries. Energy consumption is, therefore, considered as a prerequisite of sustainable economic development in the process of production. Energy consumption fuels economic growth, but also inevitably emits $\mathrm{CO}_{2}$ (Alam et al., 2016; Zhou and Liu, 2016), which is one of the major causes of creating Green House Gas (GHG) in the atmosphere and resulting global warming and climate change. Global warming and climate change affect pattern of rainfall, worsen the agricultural productivity and reduce the productivity of labour force. Accordingly, economists and environmentalists became more aware of the environmental consequences of economic growth, which shifted the attention from simple economic growth to the ecology (environment) friendly economic growth (Alam et al., 2016).
The relationship between energy consumption and economic growth, energy consumption and environmental pollution as well as economic growth and environmental pollution, has been the issue of intense research in the energy-economics literature (Acaravci and Ozturk, 2010a). Nevertheless, the empirical evidence remains controversial and unclear. The existing literature reveals that empirical studies differ substantially in terms of methods of data analysis and are not conclusive to present policy recommendation that can be applied across countries (Ozturk et al., 2010). Most of the existing studies focus either on the nexus of economic growthenergy consumption or economic growth-environmental pollutants where little effort has been made to test these two relations under the same model (Acaravci and Ozturk, 2010b).

Three research aspects in literature exist on the relationship between economic growth, energy consumption and environmental pollutants (Acaravci and Ozturk, 2010a; Alkhathlan and Javid, 2013; Jafari et al., 2015; Baek and Kim, 2011). The first aspect, which is 
considered as one of the most significant empirical relationships tested in the economic literature, focuses on the relationships between economic growth and environmental pollutants: Farhani et al. (2014b), Akpan and Abang (2015), Dinda and Coondoo (2006), Odhiambo (2011), Naraya and Narayan (2010), Kim et al. (2010), Kim and Baek (2011), Ghosh (2010) and others. The main aim of these studies are testing the validity of the environmental Kuznets curve (EKC) hypothesis which claims an inverted U-shaped relationship between the level of environmental degradation and income growth. This is to mean that environmental degradation increases with per capita income during the early stages of economic growth, and then declines with per capita income after arriving at a threshold (Acaravci and Ozturk, 2010a; Saidi and Hammami, 2015). The first empirical evidences on EKC hypothesis appeared in three independent seminal working papers (Dinda, 2004): Grossman and Krueger (1991), Shafik and Bandyopadhyay (1992) and Panayotou (1993). Literature reviews by Lapinskienè and Peleckis (2017), Stern (2004) and Dinda (2004) assert that previous EKC studies have failed to provide clear and inclusive findings on the inverted U-shaped relationship between the environment and economic growth. Moreover, Stern (2004) and Narayan and Narayan (2010) mentioned that most of the EKC literatures are based on weak econometric modelling.

The second aspect of literature emphases on the energy-economic growth nexus: Apergis and Tang (2013), Apergis and Payne (2010a), Apergis and Payne (2009b), Apergis and Payne (2009c), Chen et al. (2012), Herrerias et al. (2013). According to this relationship energy consumption and economic growth may be jointly determined, because economic growth is closely related to energy consumption as higher economic development requires more energy consumption. However, Ozturk and Acaravci (2010b) argued that the empirical literature on the energy consumption-growth nexus have yielded mixed and often contradictory results due to the different data set, countries' specific characteristics and different econometric methodologies used.

The third part of the literature combines the abovementioned lines of research in order to capture the linkages in economic growth, energy use and pollution in the same framework: Apergis and Payne (2010c), Apergis and Payne (2014), Bella et al. (2014), Alkhathlan and Javid (2013), Yang and Zhao (2014), Saboori and Sulaiman (2013), Alam et al. (2016), Rafindadi (2016), Youssef et al. (2016). However, these studies modelled carbon emissions as a function of income, income squared and/or income cubed in addition to other explanatory variables; thus, they suffered from problems of collinearity or multicollinearity (Alkhathlan and Javid, 2013).

Although a number of studies have examined the relationship between $\mathrm{CO}_{2}$ emissions, economic growth and energy consumption in developing countries, the majority of these studies have mainly concentrated on the relevance of the Environmental Kuznets Curve (EKC). Very few studies have gone the full distance to examine the nexus between $\mathrm{CO}_{2}$ emissions, economic growth and energy consumption. Even where such studies have been done, the focus has not mainly been on Sub-Sahara African countries. Studies on the causal relationship between carbon emissions, economic growth and energy consumption in sub-Saharan countries are very scant and the existing ones are not conclusive. In addition, the majority of the previous studies suffer from three major weaknesses; firstly, the use of a bivariate causality test, which may lead to the omission-of-variable bias; secondly, the use of cross-sectional data, which does not satisfactorily address the country-specific effects; as the third, the use of the maximum likelihood test based on Johansen (1988) and Johansen and Juselius (1990), which has been proven to be inappropriate when the sample size is too small (Narayan and Smyth, 2005) and they employ unit root tests which fail to consider structural breaks.

It is against this backdrop that the current study attempts to examine the causal relationship and cointegration between $\mathrm{CO}_{2}$ emissions, energy consumption and economic growth, using the newly developed TY and ARDL-Bounds testing approach. By incorporating energy consumption, population, urbanization, financial development and trade openness as control variables in a tri-variate setting between $\mathrm{CO}_{2}$ emissions, energy consumption and economic growth, this study develops a simple multivariate causality model between $\mathrm{CO}_{2}$ emissions, energy consumption and economic growth. The main objective of this paper is to analyse the significant determinants of $\mathrm{CO}_{2}$ in Ethiopia using ARDL bounds test approach to cointegration and causal relationship among variables under consideration using Toda-Yamamoto Granger causality technique. In addition, the model specifications and estimation methods have been introduced. According to the obtained results, policy recommendations are made.

\section{Material and Method}

\section{Model Specification and Data}

Unlike the recent EKC models, the earliest ones were formulated as simple quadratic functions of the levels of income. But, resources are used in an economic activity and, by the laws of thermodynamics; consumption of resources unavoidably leads to the production of waste. Due to this fact, it is asserted that regressions output that yields zero or negative levels of pollution indicators are incorrect except in the rare case and a logarithmic dependent variable should be used to enforce this restriction (Stern, 2004). Moreover, transforming variables into their natural logarithm considerably reduces or removes any heteroscedasticity problem (Hundie, 2014). Therefore, all the variables in the model of this study are in logarithmic form.

Following Farhani et al. (2014a), Shahbaz et al. (2013), Baek and Kim (2011), Ohlan (2015), Rafindadi (2016), and Zambrano-Monserrate et al. (2016), this article employs an augmented standard EKC regression to analyse the long-run relationship and direction of causality among carbondioxide emissions, energy consumption and economic growth with the intention of avoiding the omitted variable bias and collinearity problems. Abid (2017) argued that in addition to energy consumption and economic activity, environmental quality may be also affected by trade openness and financial development. Whether the degree of trade openness improves or degrades environmental quality depends on the level of economic development of a nation according to Baek and Kim (2011) and Baek, et al. 
(2009). Bo (2011), asserts that free trade may improve environment quality through technical effect or it may, exacerbate environmental pollution with the expansion of economic scale. For instance, Feridun et al. (2006) found that trade intensity has detrimental effect on environmental quality of Nigeria contrary to the finding of Zambrano-Monserrate et al. (2016) for Singapore, and Shahbaz et al. (2013) for Indonesia.

Financial development plays an important role to explain the $\mathrm{CO}_{2}$ emissions through helping companies to implement advanced technologies that are more efficient and environment-friendly resulting in reducing $\mathrm{CO}_{2}$ emissions. Besides, the financial development can attract foreign capital that improves the economic activity, which in turn influences the improvement of the environment through the implementation of projects that use this financing (Zambrano et al., 2016). In line with this, Shahbaz et al. (2013) contended that financial development decreases $\mathrm{CO}_{2}$ emissions in Indonesia. Additionally, Katircioğlu and Taşpinar (2017) propose that financial development might moderate the effects of economic activity and energy consumption on $\mathrm{CO}_{2}$ emissions.

Population growth is the core factor in explaining $\mathrm{CO}_{2}$ emission dynamics (Alam et al., 2016; Ohlan, 2015; Lin et al., 2016; Sohag et al., 2017), which should be included in $\mathrm{CO}_{2}$ emissions function if the consistent and robust result is required. African countries like Ethiopia are currently in the process of rapid urbanisation. Empirical evidences show that urbanization degrades $\mathrm{CO}_{2}$ emission through the distance people travel and the mode of transportation. Accordingly, it is important to introduce urbanisation into the model in order to determine its impacts on $\mathrm{CO}_{2}$ emission. Also, African countries depend largely on fossil fuel consumption, which increases $\mathrm{CO}_{2}$ emission. But the severity of the impact of energy consumption on the environment depends on the energy consumption structure (ES) of a country which denotes the share of clean or fossil energy in total energy consumption (Lin et al., 2016). Considering that Ethiopia is developing with substantial fossil fuel consumption, the variable ES which is the share of fossil fuel consumption (petroleum, coal and gas) in total energy consumption is included in the model. The square of GDP per capita is included to model the theoretical basis of the EKC. Therefore, the long-run relationship between energy consumption (ES), carbondioxide emissions $\left(\mathrm{CO}_{2}\right)$, GDP $(\mathrm{Y})$, square of GDP $\left(\mathrm{Y}^{2}\right)$, financial development $(\mathrm{F})$, population $(\mathrm{P})$ and urbanization (UR) can be specified as EQ (1).

The annual time series data from 1970 to 2014 on $\mathrm{CO}_{2}$ emissions measured in kilo ton (kt), energy consumption measured as proportion of fossil fuel (petroleum, coal and gas) in total energy consumption, population size, urbanization measured as percentage of the population living in urban centres, trade openness measured as ratio of export and import to real GDP, financial development index developed from financial development indicators (broad money to GDP and total reserve to GDP) using principal component analysis and real GDP. The data are obtained from the World Development Indicators (2016) online database and Ethiopian Economics Association (EEA) database.

\section{Estimation Methods}

Even though the Toda-Yamamoto (TY) and ARDL bounds test procedures are applicable irrespective of the order of integration of the series under consideration, unit root test still serves two important issues. It helps us identify the maximum order of integration for the series which is used to augment VAR (p). Moreover, the unit root test helps to identify the series with $\mathrm{I}(2)$ and above in which the ARDL procedure is inappropriate. To this end, three conventional unit root tests namely Phillips and Perron (1988) (PP), Kwiatkowski et al. (1992) (KPSS) and Augmented Dickey Fuller (1979) (ADF) were employed. Katircioglu et al. (2014) and Jafari et al. (2012) argued that PP and ADF unit root tests have a low power of rejecting the null. It is suggested that KPSS unit root test eliminates a possible low power against stationary unit root that occurs in the ADF and PP (Katircioglu et al., 2014; Jafari et al., 2012; Behera and Dash, 2017). Therefore, in order to obtain more robust results this study relied on the KPSS unit root test.

Baum (2001), however, argues that a well-known weakness of the conventional unit root tests with I (1) as a null hypothesis is its potential confusion of structural breaks in the series as evidence of non-stationarity because they may fail to reject the unit root hypothesis if the series have a structural break. Shahbaz et al. (2013) also contend that these tests provide biased and spurious results due to not having information about structural break points occurred in the series. To address this problem, Clemente et al. (1998) proposed tests that would take into account for two structural breaks within the observed history of a time series, either additive outliers (the AO model) or innovational outliers (the IO model). The double-break additive outlier AO model as employed in Baum et al. (1999) involves the estimation EQ (2).

Where $\mathrm{DU}_{\mathrm{mt}}=1$ for $\mathrm{t}>\mathrm{T}_{\mathrm{bm}}$ and 0 otherwise, for $\mathrm{m}=$ $1,2 . \mathrm{T}_{\mathrm{b} 1}$ and $\mathrm{T}_{\mathrm{b} 2}$ are the breakpoints. As stated in Baum et al. (1999), the residuals from this regression, $\widetilde{y_{t}}$, are then the dependent variable in the equation to be estimated. They are regressed on their lagged values, a number of lagged differences and a set of dummy variables needed to make the distribution of the test statistic tractable EQ (3).

Where $\mathrm{DT}_{\mathrm{bm}, \mathrm{t}}=1$ for $\mathrm{t}=\mathrm{T}_{\mathrm{bm}}+1$ and 0 otherwise, for $\mathrm{m}=1,2$. The value of minimal $\mathrm{t}$-ratio obtained from regression of Equation (3) is compared with critical values provided by Perron and Vogelsang (1992), as they do not follow the standard "Dickey-Fuller" distribution (Baum et al., 1999). The comparable model for the innovational outlier (gradual change) model expresses the shocks to the series (the effects of $\delta_{1}, \delta_{2}$ below) as having the same effect on $y_{t}$ as any other shocks, so that the dynamic effects of $\mathrm{DT}_{\mathrm{b}}$ have the same ARMA representation as do other shocks to the model. This formulation, when transformed, generates the finite $\mathrm{AR}$ model to the model, leading to the formulation of EQ (4).

Where again an estimate of $\alpha=1$ will tell us that the series has a unit root with structural break(s). Therefore, for the sake of robustness, the conventional unit root testing techniques (ADF, PP and KPSS) and unit root tests that consider structural breaks (Clemente, et al., (1998), CMR hereafter and Zivot and Andrews (1992), ZA hereafter) were employed to test for the stationarity of the variables under consideration. 


$$
\begin{aligned}
& \operatorname{lnC} C_{t}=\alpha+\beta_{1} \ln Y_{t}+\beta_{2} \ln Y^{2}+\beta_{3} \operatorname{lnE} S_{t}+\beta_{4} \ln T_{t}+\beta_{5} \ln F_{t}+\beta_{6} \ln P_{t}+\beta_{6} U R+\varepsilon_{t} \\
& y_{t}=\mu+\delta_{1} D U_{1 t}+\delta_{2} D U_{2 t}+\tilde{y}_{t} \\
& \tilde{y}_{t}=\sum_{i=1}^{k} \omega_{1 i} D T_{b 1, t-i}+\sum_{i=1}^{k} \omega_{2 i} D T_{b 2, t-i}+\alpha \tilde{y}_{t-i}+\sum_{i=1}^{k} \theta_{i} \Delta \tilde{y}_{t-i}+e_{t} \\
& y_{t}=\mu+\delta_{1} D U_{1 t}+\delta_{2} D U_{2 t}+\varphi_{1} D T_{b 1, t}+\varphi_{2} D T_{b 2, t}+\alpha y_{t-i}+\sum_{i=1}^{k} \theta \Delta y_{t-i}+e_{t}
\end{aligned}
$$

In order to test the long-run cointegration among energy consumption, $\mathrm{CO}_{2}$ emission and economic growth in Ethiopia, this study used Autoregressive Distributed Lag (ARDL) bounds test approach of Pesaran et al. (2001) due to its various advantages when compared to other cointegration techniques. An ARDL representation of Equation (1) which involves an error-correction modeling format is given as EQ (5).

The parameters $\delta_{i}$, where $i=1,2,3,4,5,6,7$, are the corresponding long-run multipliers, while the parameters $\beta_{i}, \eta_{i}, \gamma_{i}, \theta_{i}, \pi_{i} \phi_{i}, \varpi_{i}$ are the short-run dynamic coefficients of the underlying ARDL model. The first step in the ARDL bounds testing approach to cointegration is to investigate the existence of long-run relationship among all variables in the equation. To this end, an appropriate lag length selection based on Schwartz Bayesian Criterion (SBC) is conducted and Equation (5) is estimated using the OLS method. The bounds testing procedure is based on the joint F-statistic or Wald statistic that tested the null hypothesis of no cointegration, $H_{0}: \delta_{i}=0$ against the alternative of $H_{0}: \delta_{i} \neq 0, i=$ $1,2,3,4,5,6,7$ This study applies the critical values of Narayan (2005) for the bounds F-test rather than Pesaran et al. (2001) since it is based on small samples ranging from 30 to 80 observations. Two sets of critical values that are reported in Narayan (2005) provide critical value bounds for all classifications of the regressors into purely $\mathrm{I}(1)$, purely $\mathrm{I}(0)$ or mutually cointegrated. If the calculated F-statistic lies above the upper level of the band, the null hypothesis is rejected, indicating cointegration. If the calculated F-statistic is below the upper critical value, we cannot reject the null hypothesis of no cointegration. Finally, if it lies between the bounds, a conclusive inference cannot be made without knowing the order of integration of the underlying regressors.

The second step is to estimate the following long-run and short-run models that are represented in Equations (6) and (7) if there is evidence of long-run relationships (cointegration) between these variables.

Where $\Psi$ is the coefficient of error-correction term (ECT) as defined in EQ (8).

ECT shows how quickly variables converge to equilibrium and it should have a statistically significant coefficient with a negative sign (Acaravci and Ozturk, 2010a). The ARDL bounds cointegration approach proves the existence or absence of a long-term relationship between the variables included in the model (Alkhathlan and Javid, 2013), but it does not indicate the direction of causality (Acaravci and Ozturk, 2010a). Thus, this article uses Granger non-causality procedure introduced by Toda and Yamamoto (1995) (hereafter TY) to examine the causal relationship between carbon dioxide emissions, energy consumption, output, trade openness, financial development and population growth in Ethiopia. The TY approach is preferred because it has many statistical advantages over other methods of testing Granger noncausality. The basic idea is to artificially augment the correct VAR order, $\mathrm{k}$, with $\mathrm{d}_{\max }$ extra lags, where $\mathrm{d}_{\max }$ is the maximum likely order of integration of the series in the system as follows. The TY representation of Equation (1) is given as EQ (9).

We can write TY representation for the remaining variables in a similar fashion. The order $p$ of the process is estimated by some consistent lag selection criteria. In the present study we have used SIC (preferably) and AIC and $d_{\max }$ is obtained from unit root test. Then, Granger causality is tested using the modified Wald (MWald) test which is theoretically very simple, as it involves estimation of an augmented VAR model in a straightforward way. For instance, from Equation (9) energy consumption $\left(\mathrm{ES}_{\mathrm{t}}\right)$ Granger causes $\mathrm{CO}_{2}$ emissions $\left(\mathrm{C}_{\mathrm{t}}\right)$ if at least one of the $\delta_{1 p}{ }^{\prime} s \neq 0$.

\section{Results and Discussions}

\section{Unit Root Test}

Unit root test helps to identify the maximum order of integration for the series which is used to augment VAR (p). Moreover, it is used to identify the series that surpassed the order of integration I (1) under which the application of the ARDL approach is inappropriate. To this end, three conventional unit root tests viz. Phillips and Perron (1988) (PP), Kwiatkowski, Phillips, Schmidt, and Shin (1992) (KPSS) and augmented Dickey Fuller (1979) (ADF) were employed. Katircioglu et al. (2014), Jafari et al. (2012) and Farhani and Ozturk (2015) argued that PP and ADF unit root tests have a low power of rejecting the null hypothesis. It is suggested that the KPSS unit root test outshines the ADF and the PP in removing a possible low power against stationary unit root that occurs in them Katircioglu et al. (2014), Jafari et al. (2012), Behera and Dash (2017). Therefore, this study relied on the KPSS unit root test where contradictory results arise from these conventional unit root tests. The results shown in Table 1 below indicates that most of the variables, in case of $\mathrm{ADF}$, and all variables in case of PP and KPSS are non-stationary at level, but become stationary at their first difference at $5 \%$ significance level or less. This firmly proves that the conventional cointegration and granger causality testing techniques cannot be applied in this study. 


$$
\begin{aligned}
& \Delta C_{t}=\alpha_{1}+\sum_{i=1}^{p} \beta_{1 i} \Delta C_{t-i}+\sum_{i=0}^{q_{1}} \eta_{1 i} \Delta Y_{t-i}+\sum_{i=0}^{q_{2}} \gamma_{1 i} \Delta\left(Y_{t-i}\right)^{2}+\sum_{i=0}^{q_{3}} \theta_{1 i} \Delta E_{t-i}+\sum_{i=0}^{q_{4}} \pi_{1 i} \Delta T_{t-i}+\sum_{i=0}^{q_{5}} \phi_{1 i} \Delta F_{t-i}+\sum_{i=0}^{q_{6}} \omega_{1 i} \Delta P_{t-i} \\
& +\delta_{1} \ln C_{t-1}+\delta_{2} \ln Y_{t-1}+\delta_{3} \ln \left(Y_{t-i}\right)_{t-1}^{2}+\delta_{4} \ln E_{t-1}+\delta_{5} \ln T_{t-1}+\delta_{6} \ln F_{t-1}+\delta_{7} \ln P_{t-1}+\varepsilon_{1 t} \\
& \ln C_{t}=\alpha_{2}+\sum_{i=1}^{p} \beta_{2 i} \ln C_{t-i}+\sum_{i=0}^{q_{1}} \eta_{1 i} \ln Y_{t-i}+\sum_{i=0}^{q_{2}} \gamma_{1 i} \ln \left(Y_{t-i}\right)^{2}+\sum_{i=0}^{q_{3}} \theta_{1 i} \ln E s_{t-i}+\sum_{i=0}^{q_{4}} \pi_{1 i} \ln T_{t-i} \\
& +\sum_{i=0}^{q_{5}} \phi_{1 i} \ln F_{t-i}+\sum_{i=0}^{q_{6}} \omega_{1 i} \ln P_{t-i}+\sum_{i=0}^{q_{7}} v_{1 i} U R_{t-i}+\varepsilon_{2 t} \\
& \Delta C_{t}=\alpha_{3}+\sum_{i=1}^{p} \beta_{3 i} \Delta C_{t-i}+\sum_{i=0}^{q_{1}} \eta_{3 i} \Delta Y_{t-i}+\sum_{i=0}^{q_{2}} \gamma_{3 i} \Delta\left(Y_{t-i}\right)^{2}+\sum_{i=0}^{q_{3}} \theta_{3 i} \Delta E_{t-i}+\sum_{i=0}^{q_{4}} \pi_{3 i} \Delta T_{t-i} \\
& +\sum_{i=0}^{q_{5}} \phi_{3 i} \Delta F_{t-i}+\sum_{i=0}^{q_{6}} \omega_{1 i} \Delta P_{t-i}+\sum_{i=0}^{q_{7}} v_{1 i} \Delta U R_{t-i}+\psi E C T_{t-1}+\varepsilon_{3 t} \\
& E C T_{t}=C_{t}-\alpha_{2}-\sum_{i=1}^{p} \beta_{2 i} C_{t-i}-\sum_{i=0}^{q_{1}} \eta_{1 i} Y_{t-i}-\sum_{i=0}^{q_{2}} \gamma_{1 i}\left(Y_{t-i}\right)^{2}-\sum_{i=0}^{q_{3}} \theta_{1 i} E_{t-i}-\sum_{i=0}^{q_{4}} \pi_{1 i} T_{t-i} \\
& -\sum_{i=0}^{q_{5}} \phi_{1 i} F_{t-i}-\sum_{i=0}^{q_{6}} \omega_{1 i} P_{t-i}-\sum_{i=0}^{q_{7}} v_{1 i} U R_{t-i} \\
& \ln C_{t}=\beta_{10}+\sum_{i=1}^{p} \theta_{1 i} \ln C_{t-i}+\sum_{i=p+1}^{p+d_{\max }} \Omega_{1 i} \ln C_{t-i}+\sum_{i=1}^{p} \delta_{1 i} \ln E_{t-i}+\sum_{i=p+1}^{p+d_{\max }} \phi_{1 i} \ln E_{t-i}+\sum_{i=1}^{p} \gamma_{1 i} \ln T_{t-i} \\
& +\sum_{i=p+1}^{p+d_{\max }} \psi_{1 i} \ln T_{t-i}+\sum_{i=1}^{p} \mu_{1 i} \ln F_{t-i}+\sum_{i=p+1}^{p+d_{\max }} \eta_{1 i} \ln F_{t-i}+\sum_{i=1}^{p} \vartheta_{1 i} \ln P_{t-i}+\sum_{i=p+1}^{p+d_{\max }} \omega_{1 i} \ln P_{t-i} \\
& +\sum_{i=1}^{p} \varphi_{1 i} \ln Y_{t-i}+\sum_{i=p+1}^{p+d_{\max }} \mu_{1 i} \ln Y_{t-i}+\sum_{i=1}^{p} v_{1 i} \ln U R_{t-i}+\sum_{i=p+1}^{p+d_{\max }} v_{1 i} \ln U R_{t-i}+\varepsilon_{1 t} \\
& \ln E_{t}=\beta_{20}+\sum_{i=1}^{p} \theta_{2 i} \ln C_{t-i}+\sum_{i=p+1}^{p+d_{\max }} \Omega_{2 i} \ln C_{t-i}+\sum_{i=1}^{p} \delta_{2 i} \ln E_{t-i}+\sum_{i=p+1}^{p+d_{\max }} \phi_{2 i} \ln E_{t-i}+\sum_{i=1}^{p} \gamma_{2 i} \ln T_{t-i} \\
& +\sum_{i=p+1}^{p+d_{\max }} \psi_{2 i} \ln T_{t-i}+\sum_{i=1}^{p} \mu_{2 i} \ln F_{t-i}+\sum_{i=p+1}^{p+d_{\max }} \eta_{2 i} \ln F_{t-i}+\sum_{i=1}^{p} \vartheta_{2 i} \ln P_{t-i}+\sum_{i=p+1}^{p+d_{\max }} \omega_{2 i} \ln P_{t-i} \\
& +\sum_{i=1}^{p} \varphi_{2 i} \ln Y_{t-i}+\sum_{i=p+1}^{p+d_{\max }} \mu_{2 i} \ln Y_{t-i}+\sum_{i=1}^{p} v_{1 i} \ln U R_{t-i}+\sum_{i=p+1}^{p+d_{\max }} v_{1 i} \ln U R_{t-i}+\varepsilon_{2 t} \\
& \ln Y_{t}=\beta_{30}+\sum_{i=1}^{p} \theta_{3 i} \ln C_{t-i}+\sum_{i=p+1}^{p+d_{\max }} \Omega_{3 i} \ln C_{t-i}+\sum_{i=1}^{p} \delta_{3 i} \ln E_{t-i}+\sum_{i=p+1}^{p+d_{\max }} \phi_{3 i} \ln E_{t-i}+\sum_{i=1}^{p} \gamma_{3 i} \ln T_{t-i} \\
& +\sum_{i=p+1}^{p+d_{\max }} \psi_{3 i} \ln T_{t-i}+\sum_{i=1}^{p} \mu_{3 i} \ln F_{t-i}+\sum_{i=p+1}^{p+d_{\max }} \eta_{3 i} \ln F_{t-i}+\sum_{i=1}^{p} \vartheta_{3 i} \ln P_{t-i}+\sum_{i=p+1}^{p+d_{\max }} \omega_{3 i} \ln P_{t-i} \\
& +\sum_{i=1}^{p} \varphi_{3 i} \ln Y_{t-i}+\sum_{i=p+1}^{p+d_{\max }} \mu_{3 i} \ln Y_{t-i}+\sum_{i=1}^{p} v_{1 i} \ln U R_{t-i}+\sum_{i=p+1}^{p+d_{\max }} v_{1 i} \ln U R_{t-i}+\varepsilon_{3 t}
\end{aligned}
$$

Results of unit root test that consider structural breaks are given in Table 2 above. CMR unit root test result confirms that $\operatorname{lnC}, \ln \mathrm{P}$ and $\ln U R$ are stationary at level, I (0), as well as at their first difference, I (1). But lnES, $\ln \mathrm{T}, \ln \mathrm{F}, \ln \mathrm{Y}$ and $\ln \mathrm{Y}^{2}$ become stationary after first differences, i.e. they are $\mathrm{I}(1)$. This implies that $\operatorname{lnC}, \ln \mathrm{P}$ and $\operatorname{lnUR}$ are both $\mathrm{I}(0)$ and $\mathrm{I}(1)$ while the remaining variables are $\mathrm{I}(1)$. This result corroborates with the evidences obtained by the conventional unit root tests given in Table 1. Moreover, the ZA unit root test result reveals that all the variables are integrated of order one, I(1), except $\operatorname{lnC}$.

\section{Cointegration Tests}

Selection of appropriate lag length is a crucial step in estimating the ARDL model. To do so, this study employed the SBC criteria as Pesaran and Shin (1995) recommended that this criterion results in more parsimonious specifications. The results of the cointegration test based on the ARDL bounds test approach are presented in Table 3 .

Table 3 above presents estimated ARDL models, Fstatistic and optimal lag lengths selected by the SBC. Bounds F-test for cointegration reveals that there is a long-run relationship between $\mathrm{CO}_{2}$ emissions, energy intensity $(\operatorname{lnES})$, real GDP $(\ln Y)$, real GDP squared $\left(\ln Y^{2}\right.$ ), financial development (FINDEX), trade openness $(\operatorname{lnT})$, population $(\operatorname{lnP})$ and urbanization $(\operatorname{lnUR})$ at $1 \%$ level of significance since the calculated F-statistic is greater than the upper bound critical value. Moreover, the null hypothesis of no long-run relationship is rejected when each variable is considered as a dependent variable. 
Table 1 Results of conventional unit root test

\begin{tabular}{|c|c|c|c|c|}
\hline Specification & Variables & ADF: t-Statistic & PP: Adj. t-Stat. & KPSS: LM-Stat. \\
\hline \multicolumn{5}{|c|}{ Levels } \\
\hline \multirow{8}{*}{ Intercept only } & $\ln C$ & $-4.088403 * *$ & -1.553601 & $0.506271(5)^{* *}$ \\
\hline & $\operatorname{lnES}$ & -1.350324 & -1.145716 & $0.689806(5)^{* *}$ \\
\hline & $\ln \mathrm{T}$ & -1.724615 & -1.782051 & $0.599053(5)^{* *}$ \\
\hline & $\ln F$ & -1.377113 & -1.377113 & $0.501733(5)^{* *}$ \\
\hline & $\ln \mathrm{Y}$ & 4.158995 & 5.364499 & $0.812004(5)^{* * *}$ \\
\hline & $\ln Y^{2}$ & 4.745510 & 6.643138 & $0.804810(5)^{* * *}$ \\
\hline & $\ln \mathrm{P}$ & $-4.579469 * *$ & -1.971074 & $0.180746(5)^{* * *}$ \\
\hline & $\operatorname{lnUR}$ & 0.521673 & -0.202579 & $0.862220(5)^{* * *}$ \\
\hline \multirow{8}{*}{ Intercept and trend } & $\ln C$ & $-4.477194 * *$ & -2.333245 & $0.183850(4)^{* *}$ \\
\hline & $\operatorname{lnES}$ & -3.146223 & -2.826115 & $0.188741(4) * *$ \\
\hline & $\ln \mathrm{T}$ & -2.032029 & -2.273933 & $0.599053(5)^{* *}$ \\
\hline & $\ln F$ & -1.077342 & -1.077342 & $0.156875(5)^{* * *}$ \\
\hline & $\ln \mathrm{Y}$ & 0.847281 & 0.272262 & $0.218929(5) * * *$ \\
\hline & $\ln Y^{2}$ & 1.234922 & 0.616090 & $0.218657(5)^{* * *}$ \\
\hline & $\ln \mathrm{P}$ & $-4.321182 * *$ & -1.989558 & $0.116834(5)^{* * *}$ \\
\hline & $\operatorname{lnUR}$ & -2.132119 & -1.691429 & $0.147678(5)^{* *}$ \\
\hline \multicolumn{5}{|c|}{ First Differences } \\
\hline \multirow{8}{*}{ Intercept only } & $\ln C$ & $-4.850183 * * *$ & $-3.972950 * * *$ & $0.076415(3)$ \\
\hline & $\operatorname{lnES}$ & $-6.857512 * * *$ & $-7.396352 * * *$ & $0.216862(12)$ \\
\hline & $\ln \mathrm{T}$ & $-6.241112 * * *$ & $-6.267085^{* * *}$ & $0.100138(6)$ \\
\hline & $\ln \mathrm{F}$ & $-5.652532 * * *$ & $-5.660883^{* * *}$ & $0.160865(2)$ \\
\hline & $\ln Y$ & $-10.15517 * * *$ & $-9.335105^{* * *}$ & $0.760101(3)$ \\
\hline & $\ln Y^{2}$ & -12.60877 & $-8.808092 * * *$ & $0.815341(3)$ \\
\hline & $\ln \mathrm{P}$ & $-4.305795 * * *$ & -2.049215 & $0.068504(3)$ \\
\hline & $\operatorname{lnUR}$ & -1.637434 & -2.926925 & $0.157059(5)$ \\
\hline \multirow{8}{*}{ Intercept and trend } & $\ln C$ & $-5.058499 * * *$ & -3.439057 & $0.055504(4)$ \\
\hline & $\operatorname{lnES}$ & $-6.874491 * * *$ & -8.560948 & $0.190530(15)$ \\
\hline & $\ln \mathrm{T}$ & $-6.193555 * * *$ & -6.207440 & $0.095380(4)$ \\
\hline & $\ln F$ & $-5.665636^{* * *}$ & $-5.646782 * * *$ & $0.097060(3)$ \\
\hline & $\ln \mathrm{Y}$ & $-12.60877 * * *$ & -12.60877 & $0.141915(13)$ \\
\hline & $\ln Y^{2}$ & $-3.654045 * * *$ & $-12.38597 * *$ & $0.139209(10)$ \\
\hline & $\ln \mathrm{P}$ & -2.234572 & -2.016299 & $0.062434(3)$ \\
\hline & $\ln U R$ & -1.532285 & -2.842904 & $0.154517(5)$ \\
\hline
\end{tabular}

Note: *,** and *** show rejection of the null hypothesis at 10, 5 and 1 per cent level of significance respectively. Figure in brackets for KPSS is

bandwidth based on Bartlett kernel.

Table 2 Unit Root Tests with structural breaks

\begin{tabular}{|c|c|c|c|c|c|c|c|c|}
\hline \multicolumn{7}{|c|}{ Clemente-Montanes-Reyes Unit-Root Test with Double Mean Shifts } & \multicolumn{2}{|c|}{$\begin{array}{l}\text { Zivot-Andrews Unit Root test } \\
\text { allowing for a single break in } \\
\text { intercept and/or trend }\end{array}$} \\
\hline \multirow{2}{*}{ At levels } & \multicolumn{3}{|c|}{ Innovative outliers } & \multicolumn{3}{|c|}{ Additive outliers } & \multirow{2}{*}{ t-statistic } & \multirow{2}{*}{ Break date } \\
\hline & t-statistic & TB1 & TB2 & t-statistic & TB1 & TB2 & & \\
\hline $\operatorname{lnC}$ & $-6.905(2)^{* *}$ & 2002 & 2009 & $-1.815(8)$ & 2002 & 2009 & $-6.136(2)^{* * * *}$ & 2003 \\
\hline $\operatorname{lnES}$ & $-4.702(0)$ & 1984 & 1999 & $-4.822(1)$ & 1990 & 2002 & $-4.090(0)$ & 2001 \\
\hline $\ln \mathrm{T}$ & $-7.161(0)$ & 1987 & 1990 & $-3.540(7)$ & 1985 & 1993 & $-4.316(0)$ & 1992 \\
\hline $\ln F$ & $-6.679(10)$ & - & 2009 & $-3.688(0)$ & 1984 & 2008 & $-3.924(0)$ & 2005 \\
\hline $\ln Y$ & $2.111(10)$ & 1994 & 2002 & $-3.059(0)$ & 1991 & 2005 & $-2.916(1)$ & 1991 \\
\hline $\ln Y^{2}$ & $2.305(0)$ & 1992 & 2002 & $-2.983(0)$ & 1991 & 2005 & $-2.476(1)$ & 1991 \\
\hline $\ln \mathrm{P}$ & $-4.579(8)$ & 1973 & 1977 & $-6.630(1)^{* * *}$ & 1984 & 2000 & $-5.273(2)^{* * *}$ & 1992 \\
\hline $\operatorname{lnUR}$ & $-5.692(2)^{* *}$ & 1993 & 2002 & $-8.286(10)^{* *}$ & 1984 & 1997 & $-3.975(1)$ & 1990 \\
\hline \multicolumn{9}{|c|}{ At first difference } \\
\hline $\ln C$ & $-5.681(5)^{* *}$ & 1991 & 2006 & $0.235(6)$ & 1990 & 2007 & $-3.441(0)$ & 1979 \\
\hline $\operatorname{lnES}$ & $-7.873(3)^{* *}$ & 1983 & 1991 & $-7.650(1)^{* *}$ & 1982 & 1990 & $-6.946(0)^{* * *}$ & 1994 \\
\hline $\ln T$ & $-9.265(0)^{* *}$ & 1990 & 1994 & $-4.331(2)$ & 1989 & 1994 & $-8.704(0)^{* * *}$ & 1992 \\
\hline $\ln F$ & $-12.766(2)^{* *}$ & 2003 & 2009 & $-1.393(7)$ & 2003 & 2008 & $-7.547(0)^{* * * *}$ & 2001 \\
\hline $\ln Y$ & $-8.338(1)^{* * *}$ & 1992 & 2001 & $-8.165(1)^{* *}$ & 1991 & 2003 & $-13.657(0)^{* * *}$ & 1983 \\
\hline $\ln Y^{2}$ & $-14.256(0)^{* *}$ & 1992 & 2001 & $-8.168(1)^{* *}$ & 1991 & 2003 & $-13.574(0)^{* * * *}$ & 1983 \\
\hline $\ln \mathrm{P}$ & $-6.741(11)^{* *}$ & - & 1985 & $-5.348(10)$ & 1981 & 1987 & $-4.948(2)^{* * * *}$ & 1984 \\
\hline $\operatorname{lnUR}$ & $-253.986(11)^{* *}$ & 1983 & 1994 & $-1.273(8)$ & 1986 & 1996 & $-8.915(1)^{* * *}$ & 1995 \\
\hline
\end{tabular}

Note: *** and $* * *$ show rejection of the null hypothesis at 10,5 and 1 per cent level of significance respectively 
Table 3 ARDL Bounds test result

\begin{tabular}{|c|c|c|c|}
\hline Specification & Models based on BIC & F-Stat. & Result \\
\hline $\mathrm{F}_{\operatorname{lnC}}(\operatorname{lnC} \mid \ln \mathrm{ES}, \ln \mathrm{Y}, \ln \mathrm{Y} 2, \ln \mathrm{F}, \ln \mathrm{T}, \ln \mathrm{P}, \ln \mathrm{UR})$ & $(4,4,3,4,4,4,4,4)$ & $181.04^{* * *}$ & Cointegration \\
\hline $\mathrm{F}_{\operatorname{lnES}}(\operatorname{lnES} \mid \ln C, \ln Y, \ln Y 2, \ln F, \ln T, \ln P, \ln U R)$ & $(4,4,3,4,4,4,4,4)$ & $71.90^{* * *}$ & Cointegration \\
\hline $\mathrm{F}_{\operatorname{lnY}}(\ln \mathrm{Y} \mid \ln C, \ln E S, \ln \mathrm{Y} 2, \ln \mathrm{f}, \ln \mathrm{T}, \ln \mathrm{P}, \ln U R)$ & $(4,4,1,4,0,4,2,4)$ & $5.64^{* * *}$ & Cointegration \\
\hline $\mathrm{F}_{\operatorname{lnF}}(\ln \mathrm{F} \mid \ln C, \ln E S, \ln \mathrm{Y} 2, \ln \mathrm{Y}, \ln \mathrm{T}, \ln \mathrm{P}, \ln \mathrm{RR})$ & $(4,4,4,4,3,4,4,4)$ & $45.61^{* * *}$ & Cointegration \\
\hline $\mathrm{F}_{\ln \mathrm{T}}(\ln \mathrm{T} \mid \ln \mathrm{C}, \ln E S, \ln \mathrm{Y} 2, \ln \mathrm{Y}, \ln \mathrm{F}, \ln \mathrm{P}, \ln U R)$ & $(4,4,4,4,3,4,4,4)$ & $38.55^{* * *}$ & Cointegration \\
\hline $\mathrm{F}_{\ln \mathrm{P}}(\ln \mathrm{P} \mid \ln \mathrm{C}, \ln \mathrm{ES}, \ln \mathrm{Y} 2, \ln \mathrm{Y}, \ln \mathrm{F}, \ln \mathrm{T}, \ln \mathrm{UR})$ & $(4,4,4,4,3,4,4,4)$ & $44.56^{* * *}$ & Cointegration \\
\hline $\mathrm{F}_{\text {lnUR }}(\ln U R \mid \ln C, \ln E S, \ln Y 2, \ln Y, \ln F, \ln T, \ln P)$ & $(4,4,4,4,4,3,4,4)$ & $102.75^{* * *}$ & Cointegration \\
\hline
\end{tabular}

indicates significance at $1 \%$ level

The next step, after investigating the long run relationship between the variables, is to examine impacts of economic growth, economic growth squared, energy consumption, financial development, population, urbanization and trade openness on $\mathrm{CO}_{2}$ emissions. The results are reported in Table 4 showing that energy structure has positive and statistically significant impact on $\mathrm{CO}_{2}$ emissions. The coefficient of energy structure is the fourth largest (0.130386) among the statistically significant coefficients, indicating that a 1 per cent increase in the share of fossil fuel in the share of total energy consumption leads to about $.13 \%$ increase in $\mathrm{CO}_{2}$, keeping other factors constant. This implies that fossil fuel consumption is among the leading factor causing $\mathrm{CO}_{2}$ in Ethiopia. This is due to the fact that majority of the rural as well as urban population in Ethiopia which account for $88 \%$ of total energy consumption depends on biomass fuels as the energy consumption as indicated in Ramakrishna (2015). Trade openness is the second largest contributor to $\mathrm{CO}_{2}$ emissions with a coefficient of 0.195622 which implies that a $1 \%$ percent increment in trade openness leads to $0.2 \%$ increase in $\mathrm{CO}_{2}$ emissions. This finding is in line with earlier findings by Al-Mulali et al. (2016), Baek and Kim (2011) and Nahman and Antrobus (2005) which argued that trade openness has an adverse effect on the environment for the developing countries because relatively low-income developing countries will be made dirtier with trade due to the fact that pollution intensive manufacturing relocates from developed to developing countries where environmental regulations are assumed to be less strict. Under this situation, as developed countries create demand for tighter environment protection, trade openness leads to move more rapid growth of dirty industries from developed economies to developing world, thereby deteriorating environmental quality. Financial development and urbanization have no statistically significant impact on $\mathrm{CO}_{2}$. This result is in line with Kais and Sami (2016).

Economic growth is the first largest contributor to $\mathrm{CO}_{2}$ emissions in Ethiopia, with a coefficient of 0.976414 which is statistically significant at $1 \%$ level of significance. This indicates that a $1 \%$ increase in real GDP results in $0.98 \%$ increase in $\mathrm{CO}_{2}$ emissions. Contrary, a $1 \%$ rise in real GDP square reduces $\mathrm{CO}_{2}$ emissions by $0.045 \%$. This result shows that there is evidence for the existence of EKC hypothesis in Ethiopia which corroborates with the findings of Onater-Isberk (2016), Halicioglu and Ketenci (2016) for Armenia, Estonia, Kyrgyzstan, Turkmenistan and Uzbekistan and Ben Youssef et al. (2016). However, it contradicts with result obtained by Lin et al. (2016) which argued that the EKC hypothesis does not holf for African countries while it conforms with result obtained by population has statistically significant positive impact on $\mathrm{CO}_{2}$ in Ethiopia. This result corroborates the findings of earlier studies by Ohlan (2015) and Alam et al. (2016) for India. The justification is that more than $85 \%$ of the Ethiopian population which is growing at a very rapid rate, of about 3 percent annually depends on agriculture for their livelihood. This resulted in land degradation main causes for increasing numbers of people to remain in poverty, suffer from shortage of food and deteriorating living conditions. Due to this fact the population has been clearing forests and vegetation to satisfy its increasing requirements of food and energy which results in environmental degradation, in addition to the pressure put on the environment from the growing industry.

After estimating the long-run coefficients, the next step is to find the error correction representation of Equation (7) of the ARDL model. Table 5 provides the short-run results of ARDL approach to cointegration. The estimated coefficient of lagged error correction term, $\operatorname{ECM}(-1)$, is -0.103 . It is statistically significant at $1 \%$ level of significance with correct sign which indicates that departure from the long-term $\mathrm{CO}_{2}$ emissions path due to a certain shock is adjusted by $10.3 \%$ over the next year. And complete adjustment will take about 10 years. This is the alternative evidence for the existence of cointegration among the variables under consideration. In the short-run energy structure and urbanization are the only factors that are positively deriving $\mathrm{CO}_{2}$ emissions. The EKC hypothesis is not confirmed in Ethiopia in the short-run because it is not a short-run phonomena.

\section{Granger Causality}

The presence of cointegration among the variables guarantees the existence of at least a unidirectional causality (Ghosh, 2010) but it does not tell us the direction of causality. When the variables under consideration are mixture of $\mathrm{I}(0)$ and I (1) or above, the TY procedure is the most appropriate method to test for the granger causality (Chindo et al., 2014). In order to apply the TY method, the optimal lag length of VAR suggested by all lag length criteria (LR, FPE, AIC, BIC and HQ) is 2 and since the maximum order of integration is $1(d=1)$, augmented VAR (3) model was estimated using the Seemingly Unrelated Regression (SUR) framework. Table 6 presents the empirical results obtained from TY (Eq. 9-11) approach to granger causality. 
Table 4 Estimated long run coefficients

\begin{tabular}{l|cccc}
\multicolumn{1}{c}{ Variable } & Coefficient & Std. Error & t-Statistic & Probability \\
\hline $\operatorname{lnES}$ & 0.130 & 0.034582 & 3.770323 & 0.0327 \\
$\ln \mathrm{N}$ & 0.976 & 0.019382 & 50.377055 & 0.0000 \\
$\ln$ 2 & -0.045 & 0.001589 & -28.086026 & 0.0001 \\
FINDEX & -0.032 & 0.017412 & -1.828656 & 0.1649 \\
$\operatorname{lnT}$ & 0.196 & 0.050043 & 3.909071 & 0.0297 \\
$\ln \mathrm{l}$ & 0.155 & 0.018981 & 8.171453 & 0.0038 \\
$\ln U R$ & -0.121 & 0.062605 & -1.940658 & 0.1476 \\
\hline
\end{tabular}

Note: Dependent variable is InC

Table 5 Estimated short-run coefficients

\begin{tabular}{l|cccc}
\multicolumn{1}{c|}{ Variable } & Coefficient & Std. Error & t-Statistic & Probability \\
\hline $\mathrm{D}(\operatorname{lnF})$ & -0.004 & 0.006078 & -0.592988 & 0.5570 \\
$\mathrm{D}(\operatorname{lnES})$ & 0.081 & 0.023808 & 3.436712 & 0.0015 \\
$\mathrm{D}(\operatorname{lnP})$ & 0.001 & 0.026631 & 0.051413 & 0.9593 \\
$\mathrm{D}(\operatorname{lnT})$ & 0.024 & 0.017434 & 1.371461 & 0.1790 \\
$\mathrm{D}(\ln \mathrm{R})$ & 2.056 & 0.722202 & 2.847134 & 0.0073 \\
$\mathrm{D}(\mathrm{LnY})$ & -0.644 & 0.515147 & -1.250013 & 0.2196 \\
$\mathrm{D}\left(\ln Y^{2}\right)$ & 0.027 & 0.021575 & 1.270395 & 0.2123 \\
Constant & -0.025 & 0.010708 & -2.379439 & 0.0229 \\
ECM $(-1)$ & -0.103 & 0.033519 & -3.061711 & 0.0042 \\
\hline
\end{tabular}

Note: Dependent variable is $\operatorname{lnC}$

Table 6 Toda-Yamamoto Granger causality results

\begin{tabular}{|c|c|c|c|c|c|c|c|}
\hline \multirow{3}{*}{$\begin{array}{c}\text { Dependent } \\
\text { variables }\end{array}$} & \multicolumn{7}{|c|}{ Sources of Causation } \\
\hline & $\ln C$ & $\operatorname{lnES}$ & $\ln F$ & $\ln \mathrm{T}$ & $\ln \mathrm{P}$ & $\operatorname{lnUR}$ & $\ln Y$ \\
\hline & $\chi^{2}(2)$ & $\chi^{2}(2)$ & $\chi^{2}(2)$ & $\chi^{2}(2)$ & $\chi^{2}(2)$ & $\chi^{2}(2)$ & $\chi^{2}(2)$ \\
\hline $\ln C$ & - & $21.896 * * *$ & 0.150 & 0.703 & 3.803 & $4.984 *$ & $5.666^{*}$ \\
\hline $\ln E S$ & $4.833 *$ & - & 2.324 & 2.782 & 1.858 & $4.665^{*}$ & 4.553 \\
\hline $\ln F$ & 1.940 & $5.944 *$ & - & $10.173 * * *$ & $6.830 * *$ & 0.903 & 1.767 \\
\hline $\ln \mathrm{T}$ & 1.068 & 2.133 & 3.642 & - & $5.075 *$ & 0.192 & 4.380 \\
\hline $\ln \mathrm{P}$ & 0.544 & $7.878 * *$ & 3.642 & 2.749 & - & 0.032 & 1.883 \\
\hline $\operatorname{lnUR}$ & 0.940 & $17.916 * * *$ & $18.722 * * *$ & $8.910 * *$ & 3.880 & - & $10.590 * * *$ \\
\hline $\ln Y$ & 0.142 & 0.831 & $12.128 * * *$ & 3.672 & $43.215 * * *$ & $10.590 * * *$ & - \\
\hline
\end{tabular}

Notes: *,**and *** indicate significance at $10 \%, 5 \%$ and $1 \%$ respectively.

The results shown in Table 6 above can be summarized as below:

There is two-way causal relationship between $\mathrm{CO}_{2}$ emissions and energy consumption (fossil fuels as share of total energy consumption). This means that energy consumption granger causes $\mathrm{CO}_{2}$ emissions and there is feedback from $\mathrm{CO}_{2}$ emissions as well. The presence of bidirectional causal relationship between energy consumption and $\mathrm{CO}_{2}$ emissions recommends that any fluctuations in energy consumption may change the environmental quality and any effort that may reduce $\mathrm{CO}_{2}$ emissions will affect energy consumption. Moreover, bidirectional causality exists between energy consumption and urbanization. Urban areas are where economic activities and industrializations are concentrated which granger cause energy consumption.

There is no direct causal relationship between energy consumption and economic growth. Energy consumption granger causes financial development, population and urbanization and they in turn cause economic growth. Moreover, economic growth granger causes $\mathrm{CO}_{2}$ emissions. However, energy consumption affects economic growth through financial development, urbanization and population while economic growth and energy consumption are related through $\mathrm{CO}_{2}$ emissions. Population size causes financial development, economic growth and trade openness and trade openness in turn causes urbanization.

\section{Conclusion}

The main objective of this paper is to investigate the impact of population, energy consumption, economic growth, financial development, urbanization and trade openness on environmental quality $\left(\mathrm{CO}_{2}\right)$ and causal relationship between them in Ethiopia from 1970-2014. Unit root tests were conducted using conventional (ADF, PP and KPSS) and second generation (ZA and CMR) unit root test methods. The result reveals that some variables are $\mathrm{I}(0)$, others are $\mathrm{I}(\mathrm{I})$ while some of them are $\mathrm{I}(1) / \mathrm{I}(0)$. For this reason, ARDL approach to cointegration was applied to establish the long-run relationship among the variables and to obtain the estimates for both long-run and short-run effects. Moreover, Toda-Yamamoto approach to Granger causality was employed to investigate the causal relationship between the series. 
The results of the analysis show that economic growth and its square (measured by real GDP) are statistically significant positive and negative impact on $\mathrm{CO}_{2}$ emissions respectively. This finding points the presence of the evidence for EKC hypothesis in Ethiopia which implies that economic growth negatively harms environmental quality at early stage of development and becomes panacea for environmental degradation at higher stages of economic development. Therefore, the EKC hypothesis is a worthy model for environmental and sustainable development policy in Ethiopia. Energy structure is also the key factor which positively contributes to $\mathrm{CO}_{2}$ emissions in Ethiopia due to the high share of fossil fuel in total energy consumption and low penetration of clean energy in the country. Increase in population size exacerbates $\mathrm{CO}_{2}$ emissions due to the pressure that the populated human being puts on the environment. Urbanization and financial development do not affect $\mathrm{CO}_{2}$ in the long-run. However, energy structure and urbanization are factors that determine the short-run dynamics of $\mathrm{CO}_{2}$ emissions in Ethiopia. $\mathrm{CO}_{2}$ emissions are found to have a positive long-run relationship with trade openness. The TY granger causality results show that energy consumption causes financial development, urbanization and population which in turn cause $\mathrm{CO}_{2}$ emissions. Economic growth causes $\mathrm{CO}_{2}$ emissions and $\mathrm{CO}_{2}$ emissions granger causes energy consumption with feedback effect.

Based on the above findings the main policy implication that can be forwarded is summarized as follows. First, economic growth leads to more carbon dioxide emissions at lower stage of development. This implies that Ethiopia should focus on formulating environmentally friendly growth strategies and policies. Second, the degree to which economic growth affects environmental quality depends on quality and efficiency of energy used. Since energy consumption contributes to economic growth through financial development, population and urbanization, the effort of designing sustainable and environmentally favourable policy should take these variables into account. Moreover, the country should shift from fossil fuel consumption to renewable and cleaner energy sources. Third, Ethiopia should give due attention to having standard trade policies and restrictions to reduce import of environmentally pollutant products and investments.

\section{References}

Abid M. 2017. Does economic, financial and institutional developments matter for environmental quality? A comparative analysis of EU and MEA countries. Journal of Environmental Management, 188, 183-194. https://doi.org/10.1016/j.jenvman.2016.12.007

Acaravci A, Ozturk I. 2010a. On the relationship between energy consumption, $\mathrm{CO}_{2}$ emissions and economic growth in Europe. Energy, 35(12): 5412-5420. https://doi.org/10.1016/j.energy.2010.07.009

Acaravci Ali, Ilhan Ozturk. 2010b. On the Relationship between Energy Consumption, $\mathrm{CO} 2$ Emissions and Economic Growth in Europe. Energy 35 (12). Elsevier Ltd:5412-20. https://doi.org/10.1016/j.energy.2010.07.009.

Akpan Usenobong F, Dominic E Abang. 2015. Environmental Quality and Economic Growth: A Panel Analysis of the 'U " in Kuznets. Journal of Economic Research 20:317-39.
Alam MM, Murad MW, Noman AH, Ozturk I. 2016. Relationships among Carbon Emissions, Economic Growth, Energy Consumption and Population Growth: Testing Environmental Kuznets Curve Hypothesis for Brazil, China, India and Indonesia. Ecological Indicators, 70, 477-479. https://doi.org/10.1016/j.ecolind.2016.06.043

Alkhathlan K, Javid M. 2013. Energy consumption, carbon emissions and economic growth in Saudi Arabia: An aggregate and disaggregate analysis. Energy Policy, 62, 1525-1532. https://doi.org/10.1016/j.enpol.2013.07.068

Al-mulali U, Ozturk I, Solarin SA. 2016. Investigating the environmental Kuznets curve hypothesis in seven regions: The role of renewable energy. Ecological Indicators, 6, 267282. https://doi.org/10.1016/j.ecolind.2016.02.059

Apergis N, Payne JE. 2009. Energy consumption and economic growth in Central America: Evidence from a panel cointegration and error correction model. Energy Economics, 31(2): 211-216. https://doi.org/10.1016/ j.eneco.2008.09.002

Apergis N, Payne JE. 2010b. Renewable energy consumption and growth in Eurasia. Energy Economics, 32(6): 13921397. https://doi.org/10.1016/j.eneco.2010.06.001

Apergis N, Payne JE. 2010c. The emissions, energy consumption, and growth nexus: Evidence from the commonwealth of independent states. Energy Policy, 38, 650-655. https://doi.org/10.1016/j.enpol.2009.08.029

Apergis N, Payne JE. 2014. Renewable energy, output, $\mathrm{CO}_{2}$ emissions, and fossil fuel prices in Central America: Evidence from a nonlinear panel smooth transition vector error correction model. Energy Economics, 42, 226-232. https://doi.org/10.1016/j.eneco.2014.01.003

Apergis N, Tang CF. 2013. Is the energy-led growth hypothesis valid? New evidence from a sample of 85 countries. Energy Economics, 38, 24-31. https://doi.org/10.1016/ j.eneco.2013.02.007

Apergis Nicholas, James E Payne. 2010a. Energy Consumption and Growth in South America: Evidence from a Panel Error Correction Model. Energy Economics 32 (6). Elsevier B.V.:1421-26. https://doi.org/10.1016/j.eneco.2010.04.006.

Baek J, Kim HS. 2011. Trade Liberalization, Economic Growth, Energy Consumption and the Environment: Time Series Evidence from G-20 Economies. Journal of East Asian Economic Integration, 15(1): 3-30. Available from: http://www20.iadb.org/intal/catalogo/pe/2011/08700.pdf [Accessed: 12/4/2016]. ISSN: 1598-2769.

Baum CF, Barkoulas JT, Caglayan M. 1999. Long memory or structural breaks: can either explain no-stationary real exchange rates under the current float? Journal of International Financial Markets, Institutions and Money, 9(4): $\quad 359-376 . \quad$ https://doi.org/10.1016/S10424431(99)00018-9

Baum Christopher F. 2001. Stata: The Language of Choice for Time Series Analysis? Stata Journal, no. 1:1-16. https://doi.org/10.2307/2234838.

Behera SR, Dash DP. 2017. The effect of urbanization, energy consumption, and foreign direct investment on the carbon dioxide emission in the SSEA (South and Southeast Asian) region. Renewable and Sustainable Energy Reviews, 70, 96106. https://doi.org/10.1016/j.rser.2016.11.201

Bella G, Massidda C, Mattana P. 2014. The relationship among $\mathrm{CO}_{2}$ emissions, electricity power consumption and GDP in OECD countries. Journal of Policy Modeling, 36(6): 970985. https://doi.org/10.1016/j.jpolmod.2014.08.006

Ben Youssef A, Hammoudeh S, Omri A. 2016. Simultaneity modeling analysis of the environmental Kuznets curve hypothesis. Energy Economics, 60, 266-274. https://doi.org/10.1016/j.eneco.2016.10.005

Bo S. 2011. A Literature Survey on Environmental Kuznets Curve. Energy Procedia, 5, 1322-1325. https://doi.org/10.1016/j.egypro.2011.03.229 
Chen PY, Chen ST, Chen CC. 2012. Energy consumption and economic growth-New evidence from meta-analysis. Energy Policy, 44, 245-255. https://doi.org/10.1016/ j.enpol.2012.01.048

Chindo S, Abdulrahim A, Ahmad AA, Waziri SI, Huong WM. 2014. Energy Consumption, $\mathrm{CO}_{2}$ Emissions and GDP in Nigeria. $\quad$ GeoJournal, 315-322. https://doi.org/10.1007/s10708-014-9558-6

Clemente J, Montanes A, Reyes M. 1998. Testing for a unit root in variables with a double change in the mean. Economics Letters, 59(2): 175-182. https://doi.org/10.1016/S01651765(98)00052-4

Dickey David A., Wayne A. Fuller. 1979. Distribution of the Estimators for Autoregressive Time Series With a Unit Root. Journal of the American Statistical Association 74 (366):427. https://doi.org/10.2307/2286348.

Dinda S, Coondoo D. 2006. Income and emission: A panel databased cointegration analysis. Ecological Economics, 57(2): 167-181. https://doi.org/10.1016/j.ecolecon.2005.03.028

Dinda S. 2004. Environmental Kuznets Curve Hypothesis: A Survey. Ecological Economics, 49(4): 431- 455. https://doi.org/10.1016/j.ecolecon.2004.02.011

Farhani S, Chaibi A, Rault C. 2014a. $\mathrm{CO}_{2}$ emissions, output, energy consumption, and trade in Tunisia. Energy Modelling, 38, 426-434. https://doi.org/10.1016/ j.econmod.2014.01.025

Farhani S, Ozturk I. 2015. Causal relationship between $\mathrm{CO}_{2}$ emissions, real GDP, energy consumption, financial development, trade openness, and urbanization in Tunisia. Environmental Science and Pollution Research, 22(20): 15663-15676. https://doi.org/10.1007/s11356-015-4767-1

Farhani S, Shahbaz M, Sbia, R, Chaibi A. 2014b. What does MENA region initially need: Grow output or mitigate $\mathrm{CO}_{2}$ emissions? Economic Modelling, 38, 270-281. https://doi.org/10.1016/j.econmod.2014.01.001

Feridun M. Ayadi FS, Balouga J. 2006. Impact of Trade Liberalization on the Environment in Developing Countries. The case of Nigeria. Journal of Developing Societies, 22(1): 39-56. https://doi.org/10.1177/0169796X06062965

Ghosh S. 2010. Examining carbon emissions economic growth nexus for India: A multivariate cointegration approach. Energy Policy, 38, 3008-3014. https://doi.org/10.1016/ j.enpol.2010.01.040

Grossman GM, Krueger AB. 1991. Environmental impacts of a North American free trade agreement. NBER Working Paper Series, No. 3914. Available from: http://www.nber.org/papers/w3914.pdf [Accessed: 11/19/2015].

Halicioglu F, Ketenci N. 2016. The impact of international trade on environmental quality: The case of transition countries. Energy, 109, 1130-1138. https://doi.org/10.1016/ j.energy.2016.05.013

Herrerias M J, R Joyeux, E Girardin. 2013. Short- and LongRun Causality between Energy Consumption and Economic Growth: Evidence across Regions in China. Applied Energy 112. Elsevier Ltd:1483-92. https://doi.org/10.1016/ j.apenergy.2013.04.054.

Hundie SK. 2014. Savings, investment and economic growth in Ethiopia: Evidence from ARDL approach to coinegration and TYDL Granger-causality tests. Journal of Economics and International Finance, 6(10): 232-248. https://doi.org/10.5897/JEIF2014.0600

Jafari Y, Ismail MA, Othman J, Mawar MY. 2015. Energy consumption, emissions and economic growth in Bahrain. Chinese Journal of Population Resources and Environment, 13(4): 297-308. https://doi.org/10.1080/ 10042857.2015.1078493

Jafari Y, Othman J, Nor SM. 2012. Energy consumption, economic growth and environmental pollutants in Indonesia. Journal of Policy Modeling, 34(6): 879-889. https://doi.org/10.1016/j.jpolmod.2012.05.020
Johansen Soren, Juselius K. 1990. Maximum Likelihood Estimation and Inference on Cointegration-with Applications to the Demand for Money. Oxforf Bull. Econ. Stat. 52. Springer Netherlands:49-60. http://www.pubmedcentral.nih.gov/articlerender.fcgi?artid= $2860101 \&$ tool $=$ pmcentrez\&rendertype $=$ abstract .

Johansen, Soren. 1988. Statistical Analysis of Cointegration Vectors. Journal of Economic Dynamics and Control 12:231-54.

Kais S, Sami H. 2016. An econometric study of the impact of economic growth and energy use on carbon emissions: Panel data evidence from fifty eight countries. Renewable and Sustainable Energy Reviews, 59, 1101-1110. https://doi.org/10.1016/j.rser.2016.01.054.

Katircioglu ST, Feridun M, Kilinc C. 2014. Estimating tourisminduced energy consumption and $\mathrm{CO}_{2}$ emissions: The case of Cyprus. Renewable and Sustainable Energy Reviews, 29, 634-640. https://doi.org/10.1016/j.rser.2013.09.004

Katircioğlu ST, Taşpinar N. 2017. Testing the moderating role of financial development in an environmental Kuznets curve: Empirical evidence from Turkey. Renewable and Sustainable Energy Reviews, 68, 572-586. https://doi.org/10.1016/j.rser.2016.09.127

Kim SK., Baek J. 2011. The Environmental Consequences of Economic Growth Revisited. Economics Bulletin, 31(2): 1198-1211. Available from: http://www.accessecon.com/ Pubs/EB/2011/Volume31/EB-11-V31-I2-P113.pdf [Accessed: 9/8/2016].

Kim SW, Lee K, Nam K. 2010. The relationship between $\mathrm{CO}_{2}$ emissions and economic growth: The case of Korea with nonlinear evidence. Energy Policy, 38(10): 5938-5946. https://doi.org/10.1016/j.enpol.2010.05.047

Kwiatkowski Denis, Peter C.B. Phillips, Peter Schmidt, Yongcheol Shin. 1992. Testing the Null Hypothesis of Stationarity against the Alternative of a Unit Root. Journal of Econometrics $54 \quad(1-3): 159-78 . \quad$ https://doi.org/ 10.1016/0304-4076(92)90104-Y.

Lapinskiene G, Peleckis K. 2017. The evolution of the environmental Kuznets Curve concept: The Review of the research. Panoeconomicus, 64(1): 93-112. https://doi.org/ 10.2298/PAN150423012G

Lin B, Omoju OE, Nwakeze NM, Okonkwo JU, Megbowon ET. 2016. Is the environmental Kuznets curve hypothesis a sound basis for environmental policy in Africa? Journal of Cleaner Production, 133, 712-724. https://doi.org/10.1016/j.jclepro.2016.05.173

Nahman A, Antrobus G. 2005. Trade and the environmental Kuznets Curve: is Southern Africa A pollution haven? South African Journal of Economics, 73(4): 803-814. https://doi.org/10.1111/j.1813-6982.2005.00008.x

Narayan PK, Narayan S. 2010. Carbon dioxide emissions and economic growth: Panel data evidence from developing countries. Energy Policy, 38(1): 661-666. https://doi.org/10.1016/j.enpol.2009.09.005

Narayan PK. 2005. The saving and investment nexus for China: Evidence from Cointegration Tests. Applied Economics, 37(17): $\quad$ 1979-1990. $\quad$ https://doi.org/10.1080/ 00036840500278103

Narayan P.K., Smyth R. 2005. Temporal Causality and the Dynamics of Exports, Human Capital and Real Income in China. International Journal of Applied Economics, 1(1), pp.24-45. [Accessed: 25/7/2016].

Odhiambo NM. 2011. Economic growth and carbon emissions in South Africa: An empirical investigation. International Business \& Economics Research Journal, 10(7): 75-84. https://doi.org/10.19030/iber.v10i7.4668

Ohlan R. 2015. The impact of population density, energy consumption, economic growth and trade openness on $\mathrm{CO}_{2}$ emissions in India. Natural Hazards, 79, 1409-1428. https://doi.org/10.1007/s11069-015-1898-0 
Onater-Isberk E. 2016. Environmental Kuznets curve under noncarbohydrate energy. Renewable and Sustainable Energy Reviews, 64, 338-347. https://doi.org/10.1016/ j.rser.2016.06.022.

Ozturk I, Acaravci A. 2010a. $\mathrm{CO}_{2}$ emissions, energy consumption and economic growth in Turkey. Renewable and Sustainable Energy Reviews, 14(9): 3220-3225. https://doi.org/10.1016/j.rser.2010.07.005.

Ozturk I, Acaravci A. 2010b. The causal relationship between energy consumption and GDP in Albania, Bulgaria, Hungary and Romania: Evidence from ARDL bound testing approach. Applied Energy, 87(6): 1938-1943. https://doi.org/10.1016/j.apenergy.2009.10.010

Ozturk I, Aslan A, Kalyoncu H. 2010c. Energy consumption and economic growth relationship: Evidence from panel data for low and middle income countries. Energy Policy, 38(8), 4422-4428. https://doi.org/10.1016/j.enpol.2010.03.071.

Panayotou T. 1993. Empirical tests and policy analysis of environmental degradation at different stages of economic development (World Development Program Research No. 238). Geneva. Available from http://staging.ilo.org/public/libdoc/ilo/1993/93B09_31_engl. pdf [Accessed: 6/1/2016].

Perron Pierre, Timothy J. Vogelsang. 1992. Nonstationarity and Level Shifts with an Application to Purchasing Power Parity. Journal of Business and Economic Statistics 10 (3):301-20. https://doi.org/10.1080/07350015.1992.10509907.

Pesaran MH, Shin Y, Smith RJ. 2001. Bounds testing approaches to the analysis of level relationships. Journal of Applied $\quad$ Econometrics, 16, 289-326. https://doi.org/10.1002/jae.616

Pesaran MH, Shin Y. 1995. An autoregressive distributed lag modelling approach to Cointegration Analysis. Paper presented at the Symposium at the Centennial of Ragnar Frisch, The Norwegian Academy of Science and Letters, Oslo, March 3-5, 1995, 1-24. Available from: http://citeseerx.ist.psu.edu/viewdoc/download?doi=10.1.1.15 3.3246\&rep=rep1\&type=pdf [Accessed: 25/6/2017].

Phillips Peter C B, and Pierre Perron. 1988. Testing for a Unit Root in Time Series Regression. Biometrika 75 (2):335-46. https://doi.org/10.1093/biomet/75.2.335.

Rafindadi AA. 2016. Revisiting the concept of environmental Kuznets curve in period of energy disaster and deteriorating income: Empirical evidence from Japan. Energy Policy, 94, 274-284. https://doi.org/10.1016/j.enpol.2016.03.040

Ramakrishna G. 2015. Energy consumption and economic growth: The Ethiopian experience. Journal of Economic and Financial Modelling, 2(2): 35-47.

Saboori B, Sulaiman J. 2013. $\mathrm{CO}_{2}$ emissions, energy consumption and economic growth in Association of Southeast Asian Nations (ASEAN) countries: A cointegration approach. Energy, 55, 813-822. https://doi.org/10.1016/j.energy.2013.04.038
Saidi K, Hammami S. 2015. The impact of $\mathrm{CO}_{2}$ emissions and economic growth on energy consumption in 58 countries. Energy Reports, 1, 62-70. https://doi.org/10.1016/ j.egyr.2015.01.003

Shafik Nemat, Sushenjit Bandyopadhyay. 1992. Economic Growth and Environmental Quality Time-Series and CrossCountry Evidence. Policy Research Working Papers, World Development Report.

Shahbaz M, Hye QA, Tiwari AK, Leitão NC. 2013. Economic growth, energy consumption, financial development, international trade and $\mathrm{CO}_{2}$ emissions in Indonesia. Renewable and Sustainable Energy Reviews, 25, 109-121. https://doi.org/10.1016/j.rser.2013.04.009

Sohag K, Mamun M, Uddin GS, Ahmed AM. 2017. Sectoral output, energy use, and $\mathrm{CO}_{2}$ emission in middle-income countries. Environmental Science and Pollution Research, 24(10): 9754-9764. https://doi.org/10.1007/s11356-017$8599-\mathrm{z}$

Stern DI. 2004. The rise and fall of the environmental Kuznets Curve. World Development, 32(8): 1419-1439. https://doi.org/10.1016/j.worlddev.2004.03.004

Toda Hiro Y., Taku Yamamoto. 1995. Statistical Inference in Vector Autoregressions with Possibly Integrated Processes. Journal of Econometrics $66 \quad(1-2): 225-50$. https://doi.org/10.1016/0304-4076(94)01616-8.

Worlf Development Indicators. 2016. Available from: http://databank.worldbank.org/data/reports.aspx?source=wor ld-development-indicators [Accessed: 2/3/2016].

Yang Zihui, Yongliang Zhao. 2014. Energy Consumption, Carbon Emissions, and Economic Growth in India: Evidence from Directed Acyclic Graphs. Economic Modelling $38 . \quad$ Elsevier $\quad$ B.V.:533-40. https://doi.org/10.1016/j.econmod.2014.01.030.

Youssef AB, Hammoudeh S, Omri A. 2016. Simultaneity modeling analysis of the environmental Kuznets curve hypothesis. Energy Economics, 60, 266-274. https://doi.org/10.1016/j.eneco.2016.10.005

Zambrano-Monserrate MA, Christopher CL, Urgiles-Sanchez R. 2016. Is there an inverted U-shaped curve? Empirical analysis of the Environmental Kuznets Curve in Singapore. Asia-Pacific Journal of Accounting \& Economics, 1-18. https://doi.org/10.1080/16081625.2016.1245625

Zhou Y, Liu Y. 2016. Does population have a larger impact on carbon dioxide emissions than income? Evidence from a cross-regional panel analysis in China. Applied Energy, 180, 800-809. https://doi.org/10.1016/j.apenergy.2016.08.035

Zivot E, Andrews DW. 1992. Further evidence on the great crash, the oil-price shock, and the Unit-Root Hypothesis. Journal of Business \& Economic Statistics, 10(3): 251-279. https://doi.org/10.2307/1391541 